\title{
Corporate Social Responsibility for the Development of Village-Owned Enterprises: Legal Opportunities and Challenges
}

\begin{abstract}
Detania Sukarja ${ }^{1, *}$
${ }^{1}$ Universitas Sumatera Utara

Email: detasukarja@usu.ac.id

ABSTRACT

The enactment of Government Regulation No. 11 of 2021 ("PP 11/2021") following the passage of the Job Creation Law emphasizes the role of Village-Owned Enterprises (Badan Usaha Milik Desa-"BUM Desa") in Indonesia's economic and development strategy. Successful BUM Desa are viewed as supporting village economic independence. Since the passage of the Village Law and the subsequent investment in BUM Desa, there has been extensive analysis of the challenges and opportunities offered by this strategy. One of those lessons relates to the sustainability of on-going use of public funds (in particular the Dana Desa) for BUM Desa. Given these questions, there is a need to further assess opportunities for BUM Desa to access alternative sources of funds, such as those provided through Corporate Social Responsibility ("CSR") programs of the private sector. This paper aims to examine the potential of companies CSR program to support BUM Desa and the legal opportunities and challenges for the implementation. The analysis of this paper is based on a normative research method supported by qualitative interviews with 2 (two) BUM Desa in North Sumatera. Based on the discussion, the paper found that CSR practice in building partnership with UMKM has the potential to be a similar means for developing BUM Desa and the law has provided the legal basis for the involvement of companies (SOE or Non-SOE) to support BUM Desa through CSR program in various forms. Financial support for BUM Desa through companies CSR program can be either in the form of equity participation, soft loan or non-binding aid or support (such as grants or other forms). In practice, many companies have channelled their CSR to BUM Desa. PP 11/2021 provides more option for CSR distribution scheme for BUM Desa. Companies can choose the method that best suits them or the best interest of the village and BUM Desa. The CSR program for BUM Desa must be designed in a targeted and strategic manner so that it can be effective and not just a donation. Moreover, the usage of CSR programs for funding BUM Desa, in particular where it involves the contribution of funds or acquisition of assets, needs to be managed with accountability as laid out by law.
\end{abstract}

Keywords: CSR, village-owned enterprise, BUMDes, rural development.

\section{INTRODUCTION}

The idea that corporations are run solely for the benefit of shareholders have been long contested. With the rise of the stakeholder approach, companies are no longer considered as mere profit makers for shareholders but as part of the society with a more extensive scope of responsibility.[1] This is in line with the development of the 'triple bottom line' perspective advocating for nurturing business on 3 (three) separate fundamentals; profit, people and planet.[2] The evolution of this paradigm then spurred the development of Corporate Social Responsibility (“CSR") practices.
CSR has been closely associated with the concept of sustainable development. CSR practices are directed to contribute to sustainable development and assist organizations to achieve the triple bottom line performance in meeting the needs of the present and future generations.[3] It is often regarded as the panacea which will solve the global economic, social and environmental issues.[4] In weak economies, companies are expected to play 'political roles' to help the 
government in managing universal issues such as economic development, poverty and education.[5]

In line with the concept of sustainable development, since the passage of the Village Law, the Indonesian government has been extensively promoting the growth of Village-Owned Enterprises (Badan Usaha Milik Desa - "BUM Desa”) as an important tool in Indonesia's development strategy. The establishment of BUM Desa potentially offers solution to rural economic problems in the short, medium and long term, especially with regard to the development of the agricultural sector as well as micro, small and medium enterprises (Usaha Mikro, Kecil dan Menengah-“UMKM”). [6] Successful BUM Desa are viewed as supporting village economic independence.

In 2020 it was recorded that as many as 53,686 villages out of a total of 75,535 villages $(71.07 \%)$ in Indonesia has established BUM Desa. These data indicate an increase of $6.22 \%$ from 2019. [7] The government has allocated Rp795.48 trillion for regional development in the 2020 State Budget, of which Rp72 trillion is budgeted for Village Funds ("Dana Desa"). [8] BUM Desa remain as priorities for fund utilization.

With the on-going public investment in BUM Desa, there has been extensive analysis of the challenges and opportunities offered by this strategy. Many studies and assessments have been carried out to examine the sustainability of the Village Fund program in general as well as the success of BUM Desa as a tool to achieve the welfare of village communities.

Given these questions, there is a need to further assess opportunities for BUM Desa to access alternative sources of funds, such as those provided through CSR programs of the private sector. Moreover, in addition to the active role of the government, village development also needs to be supported by the participation of various parties, including business actors (private industry) The involvement of business actors through CSR programs for village and BUM Desa has the potential to accelerate the pace of the village economy. This paper aims to examine the legal opportunities and challenges of the utilization of CSR programs of companies for the development of BUM Desa.

\section{METHOD}

This paper is based on a normative research method. Analysis is drawn by examining secondary data. The discussion is also supported by qualitative interviews with BUM Desa Arih Ersada and BUM Desa Buluh Duri Mandiri in North Sumatera determined based on convenience sampling.

\section{DISCUSSION}

\subsection{CSR Revisited}

The term "corporate social responsibility" started to become well known when Howard Bowen published his seminal work "Social Responsibility of the Businessmen". Bowen defines CSR as:

"the obligations of business to pursue those policies, to make those decisions or to follow those lines of action which are desirable in terms of the objectives and values of our society". [9]

Despite being employed globally, the consensus on the definition and implementation CSR remains a debate.[10] Socially responsible actions of corporations have been variously described and used interchangeably with terms such as corporate philanthropy, corporate citizenship, corporate sustainability, corporate community involvement, global citizenship, corporate societal marketing, etc.

ISO 26000:2010 on Guidance on Social Responsibility (by far considered the most influential international guideline) defines CSR as:

"responsibility of an organization for the impacts of its decisions and activities on society and the environment, through transparent and ethical behaviour that contributes to sustainable development, including health and the welfare of society; takes into account the expectations of stakeholders; is in compliance with applicable law and consistent with international norms of behaviour; and is integrated throughout the organization and practised in its relationships." [11]

The definition of CSR in ISO 26000:2010 has also been officially adopted by the Indonesian National Standardization Board in SNI ISO 26000.

The Indonesian Limited Liability Company Law uses the term Tanggung Jawab Sosial dan Lingkungan (Social and Environmental Responsibility). The law defines CSR as:

'company's commitment to partake in sustainable economic development in order to increase beneficial life and environmental quality for the company, local community and society in general'. [12]

The Investment Law, on the other hand, also addresses CSR but uses the term "Tanggung Jawab Sosial Perusahaan" (meaning "corporate social responsibility")

In literature across the field of business and management, CSR has been prescribed as voluntary in nature.[13] The term "voluntary" is considered to mean the same with "self-regulation" in corporate activities. Self-regulation refers to rule-based constraints on 
corporate behaviour without direct intervention of the state or other external actors.[14] In this sphere, CSR implementation is dependent on the will of the company. Companies may or may not integrate CSR to their internal strategies, and that the state and other external force cannot oblige them to do so.[15] In the absence of legal requirements, companies may choose to implement CSR, regardless of the motivation. [16]

However, as Rahim provided, the ethos of CSR has not been substantially integrated in business practices in weak economies. Voluntarism and business selfregulation do not significantly contribute to social development. Developing countries starting to incorporate CSR principles into corporate statutory regulations and this had led to the rise of mandatory CSR approach.[15] According to Gond, Kang and Moon, mandatory CSR is categorized as ' $\mathrm{CSR}$ as mandated by government'.[17] In this configuration, CSR is shaped by the government and the state strongly influences the content of CSR initiatives. McBarnet refers to this similar concept as 'CSR through law'.[18]

\subsection{Mandatory CSR Regime in Indonesia}

The idea of social responsibility in Indonesian culture has been embedded in an ancient concept called "gotong royong", which means joint responsibility. Thus, the stakeholder concept is not a foreign in the Indonesian culture.[19] Gotong royong has been a living norm and social responsibility applies to all stakeholders in the community or any entity. The spirit of gotong royong is also reflected in the Indonesian economic article in the 1945 Constitution.

The implementation of CSR by companies in Indonesia was initially voluntary, as was the general trend. In general, CSR reporting is required for all limited liability companies (both public and non-public). CSR reporting is also mandatory for companies in various sectors based on sectoral laws and regulations (i.e. sustainability report in financial sector). However, the paradigm of CSR implementation in Indonesia has shifted from voluntary to mandatory after the Indonesian government saw the importance of CSR regulation in order to develop regulatory, binding and driving power. The government believes that although CSR was initially voluntary in nature, it needed to be raised to a mandatory level.[20]

When the SOE Law was enacted, the law stipulates that SOEs can use a portion of their net income to support small business and cooperative and for community development.[21] This stipulation becomes an underlying statutory basis for mandatory CSR for SOEs based on the policy that has been in place since 1983 and lastly updated with State-Owned Enterprise Minister Regulation No. PER-05/MBU/04/2021 on State OwnedEnterprises Social and Environmental Responsibility
Program or Program Tanggung Jawab Sosial dan Lingkungan Badan Usaha Milik Negara- "TJSL" (formerly known as the Partnership with Small Business Program and Community Development ProgramProgram Kemitraan BUMN dengan Usaha Kecil dan Program Bina Lingkungan- "PKBL").

The program (formerly addressed as "PKBL program" and now as "TJSL program") are aimed to increase SOEs' participation in economic, social, environmental development as well as the legal and corporate governance development for companies. The program also aims to foster micro and small businesses to become more resilient and independent as well as the community surrounding the company.[22] Successful implementation of the program becomes one of the determining indicators in rating the performance of an SOE.

For Non-SOE companies, the era of mandatory CSR implementation in Indonesia started when the Limited Liability Company Law and Investment Law were issued in 2007. Companies whose line of business are in the field of or related to natural resources must implement CSR. Government Regulation No.47 of 2012 ("PP $47 / 2012$ ") further elaborates the criteria of company that falls within this provision. Companies subject to mandatory CSR implementation must allocate budget and calculate CSR as an internal cost according to the standard of appropriateness and fairness. Non-compliant companies shall be subject to statutory sanctions.[12]

The Investment Law also stipulates that every investor must implement CSR. Investors are responsible to maintain environmental preservation. The term "investor" encompasses all investors (domestic or foreign), in limited liability company form or other company forms (sole proprietorship, general partnership or limited partnership) that are subject to Investment Law. In terms of non-compliance, the law sets administrative sanctions which include written warning, business restrictions, temporary facilities dismissal or permit revocation.[23]

Mandatory CSR initiatives have also entered the realm of local regulations. Many regions, both at the provincial and district/city levels, have enacted local regulations on the implementation of CSR by companies. Many regional heads promote CSR as an alternative financing tool to achieve local development goals.

\subsection{Channelling CSR for BUM Desa}

One of the CSR programs implemented by many companies is the strengthening of Micro, Small and Medium Enterprises (Usaha Mikro, Kecil dan Menengah - "UMKM") through partnerships. UMKM are very essential pillars in the Indonesian economy. The number of UMKM reaches 64.2 million, contributing IDR $8,573.89$ trillion to the GDP $(61.07 \%)$. The 
contribution of UMKM to the Indonesian economy includes the ability to absorb $97 \%$ of the total workforce and can collect up to $60.4 \%$ of the total investment.[24] Strengthening UMKM may overcome economic problems considering its strategic role in creating job opportunity, providing goods and services for the community, generating income, reducing economic inequality and in the long term encouraging economic growth and contributing to national stability national. However, UMKM in general experience hardship and obstacles in business development. UMKM have limited access to resources, especially to capital, technology, information and markets. [25] Therefore, the state formulates various laws and regulations that are conducive to the growth of UMKM, as well as various programs and incentives to stimulate their development.

The private sector also participates through various CSR activities for the development of UMKM. Apart from SOEs, many companies have engaged UMKM as one of their strategic stakeholders in implementing CSR. Companies create partnership to support UMKM in the form of programs such as community development, capacity building, product promotion, and capital support or strengthening for UMKM.[25]

CSR practice in building partnership with UMKM has the potential to be a similar means for developing BUM Desa. BUM Desa plays an important role as national economic pillars just like UMKM. But the underlying question is why would BUM Desa need CSR support?

In principal, most BUM Desa also falls within the same criteria with UMKM based on their business scale. In general, BUM Desa also experiences problems similar to those of UMKM. Moreover, BUM Desa actually encounter their own challenges that are different from those encountered by UMKM. Even though BUM Desa receives public funding through the Dana Desa program, many BUM Desa still struggle to be profitable.

Supporting BUM Desa has a different goal from supporting UMKM. UMKM are individual economic entities, while a BUM Desa is a public legal entity that is communally owned by the village community. In other words, supporting a BUM Desa is the same as supporting the economic development of a village whose benefits are for all members of the community.

Successful BUM Desa will have an impact on improving the village economy (i.e job creation for villagers, boosting village revenue, capital access for villagers, improving the quality of public facilities such as water, etc). In addition, it may also bring multiplier effect in achieving the village sustainable development goals (SDGs). [26] The development of business units managed by BUM Desa can also be in line with the company's line of business, so that the partnership established between the company and BUM Desa can be a mutually beneficial relationship.

\subsection{CSR Implementation for BUM Desa}

\subsubsection{CSR in BUM Desa Business Planning}

Studies have shown that many BUM Desa face difficulties in growing their business or even fail. This is because, among other things, many BUM Desa were established without a clear business plan and failed to identify their business potential and local advantages.

The preparation of a clear business plan is very important for the success of any business. In the establishment and management of BUM Desa, it is important to have a business plan to provide clear guidance for managers on governance, business execution and targets to be achieved within a certain period of time. [27] Ideally, planning should be in line with the village development goals. [28]

A business plan also needs to take into account capabilities (both financial and managerial) and anticipates business risks. More importantly, the plan should also include an estimate of the amount of capital requirements (both cash and other forms), capital utilization plan as well as funding schemes for BUM Desa business units. BUM Desa needs to plan whether funding for its business units would be entirely sourced from the village, or from a combination of village capital and community capital (other sources of equity), as well as the possibility of the need for alternative resources such as CSR. Thus, CSR as an alternative to BUM Desa business funding can be strategically included in the planning process. Clear and strategic planning can also be one of the decisive and convincing factors for companies to make BUM Desa as partners and channel their CSR.

\subsubsection{Areas of CSR Implementation}

Similar to UMKM, the CSR program targeted for strengthening BUM Desa can include internal and external factors of the business. Internal factors include supporting research and institutional development, strengthening human resource capacity and introducing technology (including digitalization) in business. While external factors include capital support, intellectual property rights facilitation, technical assistance and access to external network.[29]

As for the framework for implementation, CSR can be implemented by companies with the following options: 1) Company's direct involvement in CSR program; 2) CSR program implementation through foundations or social organizations; 3) Partnering with other parties for CSR implementation; and 4) forming or joining a consortium.[30] 


\subsubsection{CSR Distribution Scheme}

CSR programs channelled to BUM Desa through partnership programs or other scheme can be in the form of capacity development activity (such as entrepreneurship and management training for BUM Desa managers and staffs), cooperation/network facilitation, technical assistance (production, distribution and marketing), capital support/grant (cash or in-kind), providing production facilities and others. These support are expected to help improve the village economy by allowing BUM Desa to absorb more labor from the village community and increase village revenue from BUM Desa.[26]

For CSR programs that involve the distribution of funds or assets in other forms, there are 3 mechanisms for distribution. First, CSR is distributed to the village. Funds or other assets obtained by the village through CSR program then become part of the village assets which are then recorded in the Village Budget (Anggaran Pendapatan dan Belanja Desa - "APBDesa"). Then, the village will transfer capital (in cash or other forms) to BUM Desa as investment or equity participation. Further down the business structure, if BUM Desa has a business unit that is in the form of a legal entity (such as a limited liability company), BUM Desa can transfer capital to the business unit as equity participation. This mechanism is the only method that can be taken before the enactment of PP 11/2021.

Second, CSR is channelled directly to BUM Desa. Companies will transfer funds or other assets to BUM Desa (not as investment or equity participation, but as non-binding assistance or grants), which are then recorded in BUM Desa treasury. If necessary, BUM Desa can transfer the funds or assets to its legal entity business unit as equity participation. This mechanism can be implemented after PP 11/2021 came into effect (which will be explained further in point 3.5.1). Third, companies transfer CSR grants/aid directly to BUM Desa business units that are in the form of legal entities (limited liability company or cooperative).

BUM Desa managers or heads of BUM Desa business units (with the support of the village meeting and village government) can play an active role in seeking opportunities to get CSR fund distribution by submitting proposals to companies.[31] This approach is carried out when BUM Desa has strategically included CSR in their business plan as an alternative source of funding as described above. Proposals can be submitted to companies (private ones or SOEs) in the area where a BUM Desa is located. Proposals can also be submitted to specific companies that have CSR programs (often referred to as sustainability programs) that are in line with the business plans and activities of BUMD Desa and the business units.
On the other hand, the partnership between companies and BUM Desa for CSR implementation can also be initiated by companies. Companies can map and identify potential BUM Desa that require assistance and support to be their strategic partner. Companies can prioritize BUM Desa located in villages located in areas that cover the area of their business.

\subsubsection{CSR for BUM Desa in Practice}

In practice, many companies, both SOEs and nonSOEs, have channelled their CSR program to BUM Desa. For SOEs, PT Bank Mandiri (Persero), Tbk for example, provided capital support to 2 BUM Desa in Karawang Regency, BUM Desa Makmur Jaya (for sheep fattening business) and BUM Desa Bina Usaha Mandiri (for straw mushroom and quail eggs business). [32] PT. Semen Gresik also implemented PKBL for BUM Desa by disbursing funds of IDR 20.2 billion Rupiah in 20142019, which was channelled to 5 BUM Desa in Central Java through partnership programs in the fields of cleaning, landscaping/greening, vehicle rental, infrastructure, revegetation and production support, mine security and others.[33] PT.Perusahaan Listerik Negara Persero cooperated with BUM Desa Tubanan and village community in Tubanan in East Java in developing waste bank (bank sampah). [34] As for non-SOEs, PT.Astra International, Tbk and PT. Sarihusada Danone are among the many companies that are also collaborating with BUM Desa for their CSR programs.

In North Sumatera, several BUM Desa are also recipients of CSR aid from SOEs. In 2018, BUM Desa Buluh Duri Mandiri in Serdang Bedagai obtained clean toilet facilities from PT Bank Mandiri (Persero), Tbk as part of an effort to improve the quality of sanitation for Buluh Duri villagers.[35][36] In September 2021, BUM Desa Arih Ersada in Karo received CSR fund from PT. Bank Rakyat Indonesia (Persero), Tbk for the construction of water installation facilities. This facility is useful for irrigating their flower gardens which is one of the lines of business they run. [31]

\subsection{Legal Opportunities and Challenges of CSR for BUM Desa}

As can be inferred from the above discussion, CSR can be channelled to BUM Desa and many companies have implemented partnerships with BUM Desa for this purpose. To support the implementation of CSR for the development of BUM Desa, it is necessary to identify legal opportunities and challenges, as will be explained below. 


\subsubsection{Legal Opportunities}

\section{Flexibility in Designing CSR Programs}

In general, the law provides flexibility for companies (non-SOEs) to design their CSR programs and determine the target stakeholders. The Limited Liability Law and Investment Law for instance, despite mandating CSR implementation, does not stipulate a rigid legal standards for the form of CSR that must be implemented. The design and targets of the CSR program are left to the companies and they can resort to developing best practices.

PP 47/2012 adopts the "appropriateness" and "fairness" standard in CSR budgeting and programming. The regulation defines "appropriateness and fairness" as the company's policy, adjusted to the financial capacity and the potential social and environmental risks that may result from the company's business activities.[37] This standard in CSR activity designing and budgeting also applies for CSR programs aimed for BUM Desa.

Neither the Limited Liability Company Law nor PP 47/2012 further stipulates the technicalities and, hence, provides the flexibility for companies to translate these standards into their CSR programming. To support the development of BUM Desa, this flexibility is certainly beneficial because companies can freely synchronize CSR planning with the needs and business plans of BUM Desa.

\section{SOE TJSL Program for BUM Desa}

SOEs can collaborate with BUM Desa as strategic partners in implementing their TJSL program (formerly PKBL program). SOE partnership with BUM Desa for TJSL program is still in line with laws and regulation on SOEs, as well as sectoral laws and regulations pertaining to SOE line of business. This is already evidenced by the practice of many SOEs as mentioned previously.

The State-Owned Enterprise Minister Regulation No. PER-05/MBU/04/2021stipulates that the implementation of TJSL program can be in the form of financing (pendanaan), training/coaching (pembinaan) and aid (bantuan). The TJSL program is implemented based on the principles of integrated (risk based and stakeholder oriented), directed (clear direction to achieve goals), measurable (contributes and provide benefits that result in changes or added value for stakeholders and the company); and accountable (to avoid potential abuse and irregularities).[22]

The previous regulation prescribed that the cost for PKBL is derived from the net profit earned by SOEs, each set at maximum of $2 \%$ per program. The current regulation do not stipulate budget allocations for TJSL programs, but regulate more detailed standardization of program planning, implementation, supervision, monitoring and evaluation to ensure the effectiveness of the program.

The criteria for businesses that can become $\mathrm{SOE}$ partners for the TJSL program are as follow:

a. Owned by Indonesian citizens;

b. Micro and small businesses that do not meet the criteria or have access to loans from funding institutions or banks;

c. Micro and small businesses with business types that are in line with SOE's core business;

d. Independent (not directly or indirectly owned, controlled, or affiliated with a medium or large business);

e. Prioritized for businesses located in the working area of SOE; and

f. Can be in the form of individually owned business or partnerships, non-legal-entity or legal entity.[22]

Based on the above criteria, it can be concluded that micro and small scale BUM Desa with businesses in line with SOE's core business or have no access to loans are eligible to become SOE strategic partners for the TJSL programs. In other words, SOE can channel their CSR implementation to qualified BUM Desa.

\section{The Validation of BUM Desa as Legal Entities}

The Job Creation Law stipulates a new operational definition for BUM Desa that upholds its position as a legal entity. This also affirms BUM Desa legal capacity to engage in legal relationship and acquire rights and obligation. This was not clearly stipulated previously. PP 11/2021 also contains many stipulations that indirectly affirms BUM Desa legal capacity to carry out legal actions, including becoming strategic partners of companies in CSR program. Through the CSR program, BUM Desa can receive grants or other non-binding aids as well as soft loans to grow their business in accordance with the limitation and restriction prescribed in the regulation.

\section{More Flexible BUM Desa Funding Mechanism}

PP 11/2021 provides more alternatives for BUM Desa funding and more effective transfer mechanism. Funds or asset in the form of equity participation or nonbinding grant/aid from external sources can be directly transferred to BUM Desa without going through the APBDesa or directly to the BUM Desa legal entity business unit. [38]

This also applies to CSR program channelled to BUM Desa. Previously, CSR funds provided by companies (considered as grants and donations from non-binding third parties) could only be channelled to the village, and 
then transferred by the village to BUM Desa as village's equity participation. [39] If BUM Desa had business units that are corporatized as legal entities like limited liability company, then the BUM Desa would then transfer the fund to the business unit.

Referring to the discussion in point 3.5.3, accordingly PP 11/2021 provides more option for CSR distribution scheme for BUM Desa. Companies can choose the method that best suits them or the best interest of the village and BUM Desa.

\section{Stronger BUM Desa Managers Autonomy and Professional Capacity}

PP 11/2021 provides stronger autonomy and professional capacity for BUM Desa managers (pelaksana operasional) to play a more active role in acting for the best interest of BUM Desa, including in seeking the opportunity to access private sector support through CSR. This autonomy also applies to managers/directors of BUM Desa legal entity business units.

The regulation also stipulates that the organs of BUM Desa must be filled by people who are capable and have expertise. Professional governance and the success of BUM Desa can maintain the trust of donors and maintain the sustainability of the partnerships.

\section{Better Legal Framework for Better BUM Desa Governance}

PP 11/2021 promotes professionallism by prescribing more clear and detailed governance mechanism. Professionalism in the governance of BUMDes is beneficial to ensure that the management of funds or support obtained from CSR program is utilized and managed as best as possible. This also extends to the accountability mechanism. The usage of CSR programs for funding BUM Desa, in particular where it involves the contribution of funds or acquisition of assets, needs to be managed with accountability as laid out by law.

Normatively, if the companies CSR support is in the form of non-binding aid (cash or other form), managers are not directly accountable to the companies with regard to the usage or management of funds/assets acquired through CSR programs, but to the advisor (village head), supervisor and the village meeting (musyawarah desa). If the CSR support is in the form of equity participation, then managers must provide financial reports to the companies as equity partners. If the CSR support is in the form of soft loan, then managers is accountable to ensure BUM Desa repayment ability and the compliance to laws and regulations before taking the loan. Managers is also accountable to ensure that the loan is paid according to the agreed terms.
If CSR program is channelled directly to BUM Desa legal entity business units, then the accountability for the management and usage of fund/assets obtained is based on the corporate governance mechanism set in the laws and regulations pertaining to the business form. In theory, managers/directors of the business unit owe no direct accountability to BUM Desa or the village. This is line with the concept of legal entity as an autonomous subject of law.

\subsubsection{Legal Challenges}

\section{The suitability of the CSR program with the needs of BUM Desa}

Flexibility in the CSR design and budgeting is like a double edged sword. The program implementation may not necessarily entirely appropriate or suitable for the best interests of BUM Desa and village communities. Moreover, there is still a misconception that equates CSR as a donation. The CSR program for BUM Desa should be designed in a targeted and strategic manner so that it can be effective and not just a donation. The form of CSR support needs to be in line with the long-term interests of BUM Desa.

\section{Human Resource Capacity and Sustainability of CSR Program}

Various studies have shown that one of the problems with BUM Desa governance is the capacity of managers.[40] Even though the current regulations stipulate the minimum qualifications of managers and better governance standards, this is not necessarily an easy thing for BUM Desa to achieve. This of course still raises concerns that better BUM Desa governance cannot be realized immediately and CSR programs that are distributed to BUM Desa also cannot be managed properly. This may raise concern on the sustainability of CSR program to support BUM Desa in the future, if managers failed to demonstrate the ability to manage and perform.

In this case, the capacity building of BUM Desa managers must continue to be carried out, both through internal village initiatives and external support (support from the government, universities, non-governmental organizations, etc.).

\section{CONCLUSION}

CSR practice in building partnership with UMKM has the potential to be a similar means for developing BUM Desa and the law has provided the legal basis for the involvement of companies (SOE or Non-SOE) to support BUM Desa through CSR program in various forms. Financial support for BUM Desa through companies CSR program can be either in the form of equity participation, soft loan or non-binding aid or 
support (such as grants or other forms). In practice, many companies have channelled their CSR to BUM Desa. PP $11 / 2021$ provides more option for CSR distribution scheme for BUM Desa. Companies can choose the method that best suits them or the best interest of the village and BUM Desa. The CSR program for BUM Desa must be designed in a targeted and strategic manner so that it can be effective and not just a donation. Moreover, the usage of CSR programs for funding BUM Desa, in particular where it involves the contribution of funds or acquisition of assets, needs to be managed with accountability as laid out by law.

\section{REFERENCES}

[1] D. McDonald and A. G. Puxty, "An Inducement Contribution Approach to Corporate Financial Reporting," Accounting, Organizations \& Society, vol. 4, no. 1-2, pp. 53-65, 1979.

[2] J. Elkington, "Towards the Sustainable Corporation: Win-Win Business Strategies for Sustainable Development," California Management Review, vol. 36, no. 2, pp. 90-100, 1994.

[3] L. Tek-Yew and W. Y. Shyen, "How Corporate Social Responsibility contributes to sustainable development," Curtin University Malaysia, 2020. https://news.curtin.edu.my/insight/2020-2/howcorporate-social-responsibility-contributes-tosustainable-development/ (accessed Oct. 01, 2021).

[4] M. van Marrewijk, "Concepts and Definition of CSR and Corporate Sustainability: Between Agency and Communion," Journal of Business Ethics, vol. 44, pp. 95-105, 2003, doi: https://doi.org/10.1023/A:1023331212247.

[5] A. G. Scherer and G. Palazzo, "The New Political Role of Business in a Globalized World: A Review of a New Perspective on CSR and Its Implication of the Firm, Governance, and Democracy," Journal of Management Studies, vol. 48, no. 4, pp. 900-931, Apr. 2011.

[6] P. Asmanto, S. N. F. Dewi, I. Leiwakabessy, M. Maulana, and Sutikno, "Pendayagunaan Badan Usaha Milik Desa Dalam Pemulihan Ekonomi Pascawabah Covid-19," Tim Nasional Percepatan Penanggulangan Kemiskinan, Jakarta, Policy Brief, 2020. [Online]. Available: http://tnp2k.go.id/download/40000Pendayagunaan \%20Bumdes\%20Dalam\%20Pemulihan\%20Ekono mi\%20Pascawabah\%20Covid-19.pdf

[7] Badan Pusat Statistik, Statistik Infrastruktur Indonesia 2020 (Hasil Pemutakhiran Data Perkembangan Desa 2020). Jakarta: Badan Pusat Statistik, 2021

[8] Kementerian Keuangan, "Rincian Alokasi Transfer ke Daerah dan Dana Desa (TKDD) dalam APBN Tahun Anggaran 2021," Kementerian Keuangan (Direktorat Jenderal Perimbangan Keuangan), Sep. 29 ,

2020. http://www.djpk.kemenkeu.go.id/?p=17307

(accessed Oct. 01, 2021).

[9] H. Bowen, Social Responsibility of the Businessmen. New York: Harper \& Rown, 1953.

[10] R. E. Smith, "Defining Corporate Social Responsibility: A Systems Approach For Socially Responsible Capitalism," Master of Philosophy Thesis, University of Pennsylvania, Philadelphia, 2011. [Online]. Available: http://repository.upenn.edu/od_theses_mp/9

[11] International Organization on Standardization, "ISO 26000:2010: Guidance of Social Responsibility." https://www.iso.org/standard/42546.html (accessed Oct. 01, 2021).

[12] Republic of Indonesia, Law No.40 of 2007 on Limited Liability Company. 2007.

[13] P. Kotler and N. Lee, Corporate Social Responsibility: Doing the Most Good for Your Company and Your Cause. New Jersey: John Wiley \& Sons, 2005

[14] D. Graham and N. Woods, "Making Corporate SelfRegulation Effective in Developing Countries," World Development, vol. 34, no. 5, pp. 868-883, May 2006.

[15] M. M. Rahim, Legal Regulation of Corporate Social Responsibility: A Meta-Regulation Approach of Law for Raising CSR in a Weak Economy, 1st ed. Springer-Verlag Berlin Heidelberg, 2013.

[16] T. Clarke, International Corporate Governance: A Comparative Approach. Londong \& New York: Routledge, 2007.

[17] J. P. Gond, N. Kang, and J. Moon, "The Government of Self-Regulation: On the Comparative Dynamics of Corporate Social Responsibility," Economy and Society, vol. 40, no. 4, pp. 640-671, Nov. 2011.

[18] D. McBarnet, "Corporate Social Responsibility Beyond Law, Through Law, for Law," University of Edinburgh, School of Law, Working Papers 03, 2009. [Online]. Available: http://dx.doi.org/10.2139/ssrn.1369305

[19] C. H. Sedyono, "Corporate Social Responsibility (CSR) in Indonesia," in Corporate Social Responsibility in the APEC Region: Current Status and Implications, Tokyo: Institute for International Studies and Training, 2005. [Online]. Available: https://www.apec.org//media/APEC/Publications/2005/12/CorporateSocial-Responsiblity-in-the-APEC-RegionCurrent-Status-and-Implications-December2005/TOC/Indonesia.pdf

[20] B. T. Achda, "The Sociological Context of Corporate Social Responsibility Development and Implementation in Indonesia," Corp. Soc. Responsib. Environ. Mgmt., vol. 13, no. 5, pp. 300305, Nov. 2006.

[21] Republic of Indonesia, Law No.19 of 2003 on StateOwned Enterprises. 2003.

[22] Republic of Indonesia, State-Owned Enterprise Ministerial Regulation No.PER-05/MBU/04/2021. 2021. 
[23] Republic of Indonesia, Law No.25 of 2007 on Investment. 2007.

[24] Kementerian Koordinator Bidang Perekonomian and Republik Indonesia, "UMKM Menjadi Pilar Penting dalam Perekonomian Indonesia," UMKM Menjadi Pilar Penting dalam Perekonomian Indonesia, May 2021. https://ekon.go.id/publikasi/detail/2969/umkmmenjadi-pilar-penting-dalam-perekonomianindonesia (accessed Oct. 02, 2021).

[25] J. Soegiastuti, "Penerapan Strategi Corporate Social Responsibility (CSR) untuk Memperkuat Usaha Mikro, Kecil dan Menengah (UMKM)," Media Ekonomi dan Manajemen, vol. 25, no. 1, pp. 96106, Jan. 2012

[26] E. Rahmawati, "CSR untuk BUMDes Wujudkan Desa tanpa Kelaparan \& Kemiskinan," Republika Online, Nov. 2020. https://www.republika.co.id/berita/qk4cm3282/csruntuk-bumdes-wujudkan-desa-tanpa-kelaparankemiskinan (accessed Oct. 02, 2021).

[27] Departemen Pendidikan Nasional, Buku Panduan Pendirian dan Pengelolaan Badan Usaha Milik Desa (BUMDes). Malang: PKDSP Fakultas Ekonomi, Universitas Brawijaya, 2007.

[28] Suharyanto and Hastowiyono, Pelembagaan BUM Desa. Yogyakarta: Forum Pengembangan Pembaharuan Desa, 2014.

[29] Siyamtinah, "Keragaman Pola Membangun Kapabilitas Inovasi Organisasional Pada Industri Skala Kecil Menengah," EKOBIS, vol. 11, no. 1, pp. 458-468, 2010 , doi: http://dx.doi.org/10.30659/ekobis.11.1.458-468.

[30] U. Rusdianto, CSR Communications: A Framework for PR Practitioners, 1st ed. Yogyakarta: Graha Ilmu, 2013.

[31] K. Ginting, "CSR untuk BUM Desa (Upaya Pengembangan BUM Desa Arih Ersada Desa Raya)," Sep. 15, 2021.

[32] Government of West Java, "2 Bumdes Karawang Terima CSR Bank Mandiri," May 24, 2017. https://jabarprov.go.id/index.php/news/23209/2_Bu mdes_Karawang_Terima_CSR_Bank_Mandiri (accessed Oct. 02, 2021).

[33] Antara News, "Kucurkan dana CSR Rp17,2 miliar, bangun kemandirian desa sekitar perusahaan. Pencapaian Semen Gresik2019 (bagian pertama)," Jan. 06, 2020.

https://jateng.antaranews.com/berita/284072/kucur kan-dana-csr-rp172-miliar-bangun-kemandiriandesa-sekitar-perusahaan-pencapaian-semengresik2019-bagian-pertama (accessed Oct. 02, 2021).

[34] D. Putri, E. Susilowati, and S. Mahmudah, "Upaya Peningkatan Ekonomi Masyarakat Desa Melalui Corporate Social Responsibility," Diponegoro Law Journal, vol. 6, no. 2, 2017, [Online]. Available: http://www.ejournal-s1.undip.ac.id/index.php/dlr/
[35] B. Purba, "CSR untuk BUM Desa (Upaya Pengembangan BUM Desa Buluh Duri Mandiri)," Sep. 15, 2021

[36] PT.Bank Mandiri (Persero) Tbk, "Sustainability Report 2018," Apr. 2019.

[37] Republic of Indonesia, Government Regulation No.47 of 2012 on Social and Environmental Responsibility of Limited Liability Companies. 2012.

[38] D. Sukarja, M. Siregar, and T. M. Lubis, "An Analysis of The New Regulation on The Governance of Village-Owned Enterprises,' presented at the The 4th International Conference on Indonesian Legal Studies, Semarang, Jun. 2021.

[39] R. T. N. Soemadji, I. Ikhwansyah, and P. Faisal, "Pertanggungjawaban Hukum Badan Usaha Milik Desa atas Pengelolaan Dana Corporate Social Responsibility yang Diberikan oleh Perusahaan untuk Pengembangan Badan Usaha Milik Desa Melalui Anggaran Pendapata Belanja Desa," ACTA DIURNAL, vol. 3, no. 1, pp. 98-112, Dec. 2019, doi: http://dx.doi.org/10.24198/acta.v3i1.384.

[40] D. Sukarja, M. Siregar, and T. M. Lubis, "Implementing Good Corporate Governance Principles by Village Owned Enterprises: A Case Study From North Sumatera," presented at the 1st International Conference on Trade, Business, Human Rights, and Globalization, Makassar, Nov. 2019. 